DOI: $10.20472 / T E .2019 .7 .2 .001$

\title{
IMPLEMENTATION OF PHYSICS LEARNING BASED ON HYPERMEDIA TO ENHANCE STUDENT'S PROBLEM SOLVING SKILL
}

\author{
BUNGA DARA AMIN, ABDUL HARIS, AHMAD SWANDI
}

\begin{abstract}
:
The objectives of this research were to examine the effect of hypermedia's implementation as physics learning tools on student's problem solving skills as well as their attitude towards the hypermedia used. The type of research was pre-experimental using one group pre-test-post-test design. The subject of this research was physics students of Fakultas Keguruan IImu Pendidikan (FKIP) or Teaching and Education Faculty, Universitas Muhammadiyah Makassar year 2017/2018 totalling 31 students. Data was analyzed by using descriptive statistics namely N-Gain test. The results showed that the highest score of problem solving skill achieved before the implementation of hypermedia was 32 and 63 after the implementation from the ideal score of 76. N-Gain analysis showed the average improvement of problem solving skills before and after the implementation was 0.59 and in category average $74.19 \%$. Score of every indicator of problem solving skills before the implementation was below $50 \%$ and above $50 \%$ afterwards. Meanwhile, perception analysis showed that the average score was $84.12 \%$ indicating that students were highly agree and happy with the implementation of hypermedia in physics learning.
\end{abstract}

\section{Keywords:}

Hypermedia learning tools, Problem solving skills, Physics education, Learning activity

JEL Classification: 123

\section{Authors:}

BUNGA DARA AMIN, Makassar State University, Indonesia, Email: bungadara57@gmail.com ABDUL HARIS, Makassar State University, Indonesia, Email: abd.haris@unm.ac.id AHMAD SWANDI, Makassar State University, Indonesia, Email: ahmadfisika40@gmail.com

\section{Citation:}

BUNGA DARA AMIN, ABDUL HARIS, AHMAD SWANDI (2019). IMPLEMENTATION OF PHYSICS LEARNING BASED ON HYPERMEDIA TO ENHANCE STUDENT'S PROBLEM SOLVING SKILL . International Journal of Teaching and Education, Vol. VII(2), pp. 1-11., 10.20472/TE.2019.7.2.001 


\section{Introduction}

Information and Communication Technology (ICT) is growing fast influencing all aspects of our life, including our education system. Almost all schools and higher institutions have been equipped with ICT facilities to improve the learning process specially in science. The impact of the rapid development of science and technology can easily receive information to use computer media. Computer media is growing so rapidly in accordance with the development of technology and communication (ICT) that it is possible to develop learning processes with interactive multimedia. In accordance with the new paradigm of 21st Century learning, according to Indrajit, (2011) and Badan Standar Nasional Pendidikan (BSNP) or National Education Standard Body, (2010) states that: (1) One-way learning patterns (lecturer-student interactions) become interactive learning (interactive lecturers-student-communityenvironment, sources/ media others); (2) Single tool learning patterns become multimedia based learning; (3) From virtual/abstract to real world contexts and (4) Mass-based learning patterns become the needs of customers (users) by strengthening the development of the special potential of each student.

The use of ICT is expected to enhance the education quality. According to observations in several universities in Makassar city, majority of students uses ICT specially smartphone to find information from many sources to make easy for them to understand and solve various problems they face in the lesson, the use of the internet as a learning resource is far greater than other sources such as books and articles. students can access many learning resources and compare with other sources.

One form of technology use in learning is hypermedia. Hypermedia is an extension to what is known as hypertext, or the ability to open new web pages by clicking text links on a web browser. Hypermedia extends upon this by allowing the user to click images, movies, graphics and other media apart from text to create a nonlinear network of information. The term was coined by Fred Nelson (1965). Oliver and Herrington (1995) pointed out that the use of Hypermedia increasing along with the computer technology and become a factor in creating student centre learning.

Hypermedia is collection of learning media based on computer consisting of text, graph, animation, videos and audios that can be used optimally by students in their own time and space (Jeanne, 2008). According to Amin et.al (2016), the hypermedia which is developed with category of valid, practical, and effective influence the learning outcomes of student at Makassar State University.

It is believed that learning and teaching process using hypemedia are able to create laerning environment which is centered to student and resulting adaptation among them, facilitating supporting tools to express idea and concepts, interactive, and creating feedback or evaluation of student work, as well as direct interaction by using 
internet. Research result showed that hypermedia can be applied to improve learning quality in higher education. Based on initial observation on physics student at Fakultas Keguruan dan IImu Pendidikan (FKIP) or Teaching and Education Faculty, Universitas Muhammadiyah Makassar 2017/2018, it was found that the ability of student in problem solving was low in terms of interpreting abstract concept in the form of table, graph, and mathematical symbols, as well as numerical competence. Such capabilities can actually be improved either manually or by using a computer. On the other hand, student have their own computer or laptop as well as other communication tools to access internet which can help to do assigment. Therefore, the results of various studies on the use of hypermedia in physics learning cannot be used as conclusions in general, further research involving more samples and various methods is still needed in order to reach the convincing effect of the hypermedia implementation in physics learning. So, by applying physics learning tools based on hypermedia it is expected to improve the skills of student's problem solving at physics Departement FKIP, Universitas Muhammadiyah Makassar. According to Fabos (2011), the hypermedia is a revolution in learning because hypermedia not only consist of text, graphics, video and audio, but also provide network to be accessed by students. Beside that the use of hypermedia in learning magnetic induction improved the mastering of concept and generic skill of students (Setiawan, 2007).

Furtheremore, Swandi et.al (2017) reported that learning by using virtual laboratory based on hypermedia was able to improve activity and student's motivation in learning process. The use of hypermedia in physics learning has been done by several researchers, but most of the research only describes the influence of the use of hypermedia-based teaching materials on improving student learning outcomes and does not specifically investigate each indicator of how students solve each given physics problem.

\section{Method}

\section{Research Type}

This study was pre- experimental research using the One Group Pretest- Postest Design. Before being given treatment with the application of learning instrument based on hypermedia, students were first given a test to identify their initial knowledge. then, students were treated through the application of learning instrument based on hypermedia for 5 meetings. After the learning process was completed, students were given a posttest in order to acquire information about their learning achievement as a result of the implementation of hypermedia. The pretest an posttest scores were used to calculate the N-Gain of student's achievement to be used to evaluate the effect of hypermedia on student's problem solving skills.

\section{Subject}

The subject of this research was Physics Education students, FKIP, Universitas Muhammadiyah Makassar year 2017/2018 comprising 31 students. 


\section{Instruments}

The instruments used in this study were questionnaire of student's perception towards physics learning using hypermedia and problem solving skills test.

\section{Data collection}

The technique of data collection was divided into there parts: Observation, Problem solving test, and Questionnaire about student's perception towards physics learning.

\section{Data Analysis}

Data collected was analyzed quantitatively as well as qualitatively. Problem solving skills was analyzed quantitatively to know the N-Gain of student's achievement by using equation:

$$
\text { (g) }=\frac{S_{\text {post }}-S_{\text {pre }}}{S_{\max }-S_{\text {pre }}}
$$

Note :

(g) = N-gain,

$\mathrm{S}_{\text {post }}=$ Posttest Score,

$S_{\text {pre }}=$ Pretest Score,

$\mathrm{S}_{\max }=$ Maximum score.

The result of $\mathrm{N}$-Gain calculation was tabulated categorically in Table 1.

\section{Table 1: $\mathbf{N}$-Gain Criteria}

\begin{tabular}{|l|l|}
\hline $\mathbf{N}$-gain Score & Criteria of Normalized Gain \\
\hline $0.70<\mathrm{N}$-gain & High \\
$0.3<\mathrm{N}$-gain $<0.70$ & Moderate \\
$\mathrm{N}$-gain $<0.30$ & Low \\
\hline
\end{tabular}

\section{Student's perception analysis}

In order to describe student's perception towards physics learning based on hypermedia, the following equation was used,

$$
P=\frac{\sum R}{\sum N} \times 100 \%(\text { Jeanne, 2008) }
$$

Note:

$\mathrm{P}=$ Percentage of student's response,

$\sum R=$ Number of response,

$\sum N=$ Total Respondent. 


\section{Results and Discussion}

\section{Analysis of student's problem solving score}

Table 2 showed the difference in student's problem showing score before and after the implementation of learning tools based on hypermedia.

Table 2: Score of student's problem solving skill

\begin{tabular}{|l|c|c|}
\hline \multicolumn{1}{|c|}{ Statistic } & Pretest & Score of problem solving pretest \\
\hline Sample size & 31 & 31 \\
\hline Highest score & 32 & 63 \\
\hline Lowest score & 0 & 26 \\
\hline Ideal score & 76 & 76 \\
\hline Score interval & 32 & 37 \\
\hline Average score & 15.72 & 50.96 \\
\hline Standar devidtion & 6.70 & 36.54 \\
\hline Variant & 44.98 & $1,335.54$ \\
\hline
\end{tabular}

Based on the table above, it can be seen that there is an increase in the average results of problem-solving student skills from 15.72 to 50.96 . Distribution of problem solving score of pretest and posttest is showed in Figure 1.

Figure 1: Percentage distribution of pretest and postest of student problem solving skill

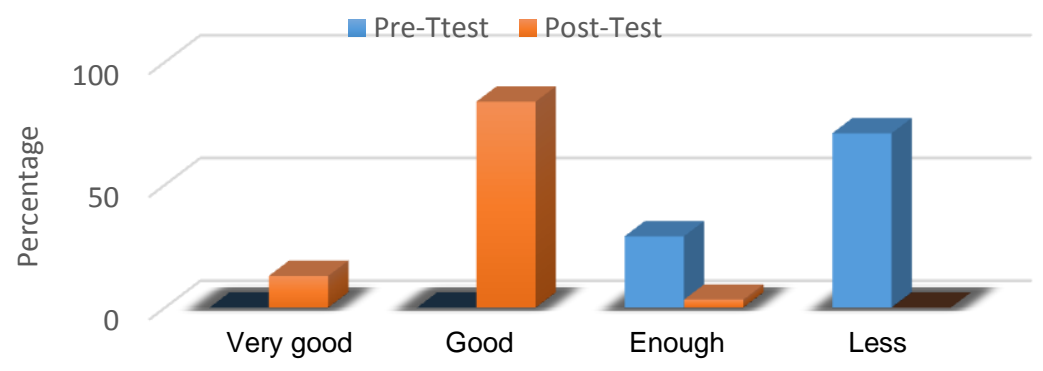

Based on Figure 1, for the pre-test there were $29.03 \%$ of the number of students who obtained the value of sufficient categories and $70.93 \%$ with the less categories. There are no students who get good and very good grades. As for the post-test results, there were $12.90 \%$ of the number of students who obtained very good grades, $83.87 \%$ obtained grades with good categories and $3.23 \%$ of students obtained sufficient grades. From these data it can be seen that there is an increase in the percentage of results of student problem solving tests for each category.

Next, N-gain analysis is performed to obtain the category of increase in each distribution. The improvement of problem solving score after the implementation of hypermedia can be seen in Table 3 . 
Table 3: Frequency distribution and percentage of problem-solving skills

\begin{tabular}{|c|c|c|c|}
\hline Criteria & Category & Frequency & Percentage (\%) \\
\hline $\mathrm{g}>0.7$ & High & 7 & 22.5 \\
\hline $0.3<\mathrm{g}<0.7$ & Moderate & 23 & 74.19 \\
\hline $\mathrm{g}<0.3$ & Low & 1 & 3.23 \\
\hline
\end{tabular}

From the data set it can be seen that, based on the $\mathrm{N}$-gain value there are 7 students who have a high increase category, and 23 students have enough improvement categories. There was only one student with a low increase category. In general, it was found that the average improvement of problem-solving skills was 0.59 and it is categorized as an average.

There are four indicators of problem solving skills used in this research (Amin, et.al. 2016), namely problem mapping (PM), Mathematics and numerical skill (MN), space and graph (SG) and Estimation-Approximation (EA). Data of percentage of every indicator is shown in Table 4.

Table 4: Comparison of percentage of every indicator of problem-solving skill

\begin{tabular}{|c|c|c|}
\hline \multirow{2}{*}{ Indicator } & \multicolumn{2}{|c|}{ Percentage (\%) } \\
\cline { 2 - 3 } & Pretest & Post-test \\
\hline Problem Mapping & 26.34 & 70.16 \\
\hline Mathematics and Numerical & 17.28 & 70.73 \\
\hline Space \& Graph & 23.79 & 51.61 \\
\hline Estimation-Approximation & 17.74 & 63.91 \\
\hline
\end{tabular}

From Table 4 it can be seen that in general there is an increase in the percentage of pretest to posttest for all indicators of problem solving skills. Mathematics and numerical skills have the highest increase of $53.45 \%$, while problem mapping skills are 43.82 and space/graphic skills and estimates are $27.82 \%$ and $46.17 \%$ respectively. So it can be concluded, that the use of a hypermedia based worksheet is able to increase the percentage of student problem solving skills for all indicators. It can be seen that there is a significant difference in problem solving skill of student before and after the implementation of hypermedia in aspect mathematics and numerical skills, space and graphs, as well as estimation and approximation. Some studies showed that there is an increase in student learning outcomes after being taught to use hypermedia characterized by interactive simulations shows that the implementation of student worksheets of physics is based on virtual simulation can improve student learning outcomes in high levels.

The factors that led to an increase in problem solving skills were the completeness of the hypermedia and the student worksheets provided. The questions presented in student worksheets are intended to train them in mapping out existing problems. Students are guided to do mathematical and numerical analysis of existing observation data. In addition, these data are then connected to each other to obtain a certain quantity or variable. The estimation skills and approximation of students 
grow by testing the concepts they know with interactive simulations that are able to clearly show invisible physical phenomena.

\section{The analysis result of student's perception towards learning based on hypermedia}

There are there indicators which used to determine student's perception, and the results can be seen in Table 5 .

Table 5: Student's perception

\begin{tabular}{|c|c|}
\hline Indicator & Percentage (\%) \\
\hline Hypermedia based learning facilities & 84.61 \\
\hline Learning interest using hypermedia & 85.37 \\
\hline Learning activity using hypermedia & 82.37 \\
\hline
\end{tabular}

Based on Table 5, it is known that for all perceptual indicators above $80 \%$ and $85 \%$ with indicators strongly agree. The average of student's perception towards hypermedia is $84.12 \%$ which is in strongly agree category. This indicates that learning using hypermedia recieved high interest of students and suitable to be implemented. However, there are a number of suggestions given by students such as the complete concept in hypermedia which is still lacking, the existing interactive simulations cannot be enlarged, making it difficult for students to observe physics concepts. some students also suggested that there was an initial activity such as a tutorial given by the lecturer to students about the use of hypermedia.

Furthermore, students are very interested in using hypermedia because of several reasons, first they can observe abstract concepts directly. The behavior of various objects that cannot be seen directly like electrons can be observed using this simulation. Secondly, student worksheets make them more active in attending lessons. they can make observations, analyze data obtained from observations, answer various questions given and deliver their learning results directly. Finally, this learning train them in creating and releasing a graph and determining the variables of a graph with regression analysis.

The basic concept states that perception is the beginning of all kinds of learning activities that can occur on every occasion, intentional or not. Perception occurs because every human being has the senses to absorb objects and events. At the end, perceptions can influence the way of thinking, working, and behaving on someone. This happens because the person in digesting information from the environment manages to adapt the attitudes, thoughts, or behaviors to the information. This is in line with Thurstone in Azwar (1995) that perception is part of attitude in the form of evaluation or feeling reaction, a person's attitude towards an object is a feeling of supporting or favorable (feeling) not supporting (unfavorable) on 
an object. More specifically, Thurstone himself formulates attitudes as the degree of positive affect or negative affect on an object. Perception is a psychological process and the results of sensing and the last process of consciousness, thus forming the thinking process. Furthermore, Warsita (2008:261) based on observations on the ground that $90 \%$ of learning success was caused by a pleasant psychological atmosphere. This psychological atmosphere can be created, shaped, and conditioned. Based on the research of experts, the brain can be optimally absorbed if it is psychologically happy so that the valve in the brain is open. Under these conditions the brain can work very well. Several studies to find out the opinions of students about the use of interactive simulations in physics learning were carried out by several researchers such as those conducted by Swandi, et al (2015), which showed that the percentage of students' perceptions was $93.05 \%$ indicating that they strongly agreed to virtual simulation physics learning. In addition, research conducted by Irfan et al (2015) showed that students' perceptions of $78.53 \% \pm$ SD 4.9 indicated that students strongly agreed to the learning activities carried out.

Based on observation during learning process in which students were actively involved and independently using hypermedia, students were able to develop their own knowledge. This results are in accordance with those reported by Yulianti and Swandi (2016) which reported that the implementation of hypermedia was able to develop the affective ability of students which describe interest, and attitude Towards Learning (Chengiz, 2010). Besides that, Warsita (2008) observed that $90 \%$ of learning results influenced by physicological environment. Physicologycal feeling could be created, farmed, and conditioning. Neurological experts pointed out that the ability of human brain to absourt information depends on physicological condition.

Based on the graph of student activity depiction, it was found that there was an increase in the activity of students in the given learning material, this was due to students getting used to the use of instructional media, it could be categorized that individually, students are active in learning virtual laboratory-based media physics. This is in line with Paul in Munir (2008) that the activities of students in computer media-based learning activities include various activities that at least make students active, namely visual activities (reading, paying attention to pictures, experiments, other people's work), oral activities (stated, formulate, ask, give advice, issue opinions), listening activities (listening to descriptions, conversations, discussions), writing activities (writing stories, reports, copying), drawing activities (drawing, making graphics, diagram maps, patterns), motor activities (experiment, model, maintain), mental activities (consider, remember, solve problems, analyze, see relationships), and emotional activities (interest, feeling bored, happy, brave, calm, nervous).

Descriptive analysis showed that the average score of problem solving skills in the aspects of problem mapping, space and graphs, as well as estimation approximation is higher than the score of problem solving skills before the implementation of 
hypermedia. This is caused by the ability of students to develop their own knowledge based on real experience. Students why do not recieve learning using hypermedia tends to wait information from their lecturer. Hypermedia gives the apportunity of students to learn together, active, motivated, as well do obtain feed back from their lecturer.

The improvement of problem solving skills after the implementation of hypermedia was analyzed by using normalized $\mathrm{N}$-gain after the implementation of hypermedia. The results of this study was supported by the research of Swandi et.al (2015) which found that the implementation of hypermedia made the abstract concept become easy to understand through demonstration and joyful learning. The other benefits of using hypermedia is the weaknesses found in lecturer can be corrected through obsevation,concrete examples, or using real objects.

The development of information and communication technology requires high-level thinking competencies, including problem solving to be developed in learning both at the secondary school level and at the university level. So that it is guided to design innovative learning that is able to teach students to find facts, and information, can process and develop it so that it becomes something valuable and useful for themselves. To achieve learning objectives optimally, an educational tool or learning media is needed. According to Jonassen, Howland, and Moore (2003) in Sharon E. Smaldino et.al, (2011) states that through computer media which is a sophisticated tool and can be utilized, among others, on the issue of education and learning.

Therefore the use of computer software in learning allows students to interact directly. This shows that computer simulations are interactive multimedia that can develop problem solving skills. The interactive multimedia that will be developed in this study is the type of hypermedia with simulation and Virtual Real Laboratory for various abstract physics concepts through self-developed projects with basic simulations adapted from www.kcvs.ca. McKagan, et. Al (2008) concluded that students are easier to interpret, understand abstract concepts in quantum physics. This is supported by the results of the study stating that: Abstract concepts such as the particle wave dualism can be understood by students with the help of interactive multimedia learning models (Budiman, 2008 in Wiyono, 2009); and M. Sutarto (2011) found that generic science skills of students who took interactive multimedia learning were significantly higher compared to students following conventional learning. By utilizing the advantages of computers, computers can be used as media and learning resources in certain fields of study in addition to other media. Various researches have been conducted to determine the effectiveness of computer use in learning. In addition, in Tawil's research (2013) found that there was an increase in understanding of concepts and creative thinking skills taught by computer-based simulation learning compared to conventional learning. 
Research conducted by Amin et.al (2017) pointed out that the ability of students improve after the implementation of hypermedia (Suputro, et al. 2015). This is understood since the use of hypermedia will give student background of the subject through hypermedia which improve their concept understanding.

\section{Conclusion}

The results of this study showed that physics learning tools based on hypermedia influencing the improvement of problem solving skills of physics students of FKIP Universitas Muhammadiyah Makassar.

Based on the results findings and data analysis, it can be concluded that (1) physics learning tools based on hypermedia can improve problem solving skills of students in the aspect of problem solving, mathematical skill, space and graphs awereness, as well as estimation-approximation. (2) based on the results of the analysis of student perceptions of the use of hypermedia and student worksheets, was in high categories associated with the use of hypermedia and student worksheets in physics learning. (3) based on observations made by observers, students are very active in participating in all learning. This learning tools is suitable to be used in physics lecture.

\section{References}

Amin, B.D., Mahmud, A., Muris (2016). The development of physics learning instrument based on hypermedia and its influence on the students problem solving skill, ISSN 2222-1735, Vol. 7, No.6, 22-28.

Amin, B. D., Swandi, A., \& Haris, A. (2017). Implementation of physics learning instrument based on hypermedia to increase science process skill. Proceeding of International Seminar on Science Education, ISSN 24769533, Vol. III: 175-182.

Cengiz, T. (2010). The effect of the virtual laboratory on student's achievement and attitude in chemistry. Online Journal of Educational Sciences,2(1), 37-53.

Fabos, D. (2011). Media in the classroom an alternative history. Paper Presented at the Annual Conference of the American Educators Research Association, Scattle, WA. (ERIC Document Reproduction Service, No. ED 454850).

Finkelstein, N., Wendy A. (2006). Interactive simulation for teaching and learning physics. Jurnal The Physics Teacher, Vol. 44, Januari 2006. https://doi.org/10.1119/1.2150754

McKagan, S. B., K. K., Perkins, M., Dubson, C., Malley, S., Reid, R., LeMaster, C. E., Wieman (2008). Developing and researching phet simulation for teaching quantum mechanics. Physics Education Technology Journal. https://doi.org/10.1119/1.2885199

Sutarto, M. (2011). Penggunaan multimedia interaktif pada pembelajaran medan magnet untuk meningkatkan keterampilan generik mahasiswa. Jurnal Exacta, Vol. IX, No. 1.

Ranjana, Y. A. (2005). Making introductory quantum physics understandable and interesting. 
Resonance Journal, Volume 10, Issue 1, pp. 63-73. https://doi.org/10.1007/BF02835894

Ron Oliver \& Jan Herrington (1995). Developing effective hypermedia instructional materials. Australian Journal of Educational Technology, 1995, 11(2). https://doi.org/10.14742/ajet.2073

Saputro, R. P., Wasis \& Koestiari, T. (2015). Pengembangan perangkat pembelajaran fisika model discivery learning untuk meningkatkan hasil belajar dan ketrampilan berpikir kreatif. Jurnal pendidikan Sains Pascasarjana Universitas Negeri Surabaya, ISSN 20891776, Vol 5., No. 1, November 2015, 693-702.

Sharon, E, Smaldino, Deborah L., Lowther (2011). Instructional technology \& media for learning. Edisi Kesembilan, Penerbit Kencana, Jakarta.

Setiawan, et. al. (2007). Influence of hypermedia instruction model on magnetic induction topic to comprehension of physics concept and sciences generic skill of physics teacher. Proceeding of First International Seminar on Science Education, SPS UPI Bandung.

Steinberg, R.N., Oberem G.E., McDermott, L.C. (1996). Development of a computer-based tutorial on the photo-electric effect. Am. J. Phys. 64, 1370-1379. https://doi.org/10.1119/1.18360

Swandi, A., \& Amin, B.D. (2017). Development of physics learning instrument on hypermedia and its influence on concept comprehension of physics student. Proceeding of International Seminar on Mathematic, Science Education and Computer Science Education, ISBN 978-602-95549-46, 68-74.

Swandi, A., Amin, B. D., Haris, A., \& Subaer (2015). Development of virtual laboratory hypermedia based on atomic physics at SMAN 1 Pinrang. Proceeding of International Conference on Research, Implementation and Education of Mathematics and Sciences, 1(1), 7-8.

Swandi, A., \& Amin, B. D. (2016). The development of student's worksheet based on virtual simulation and its influence on physics learning outcomes of students. Proceeding of International Conference on Mathematics, Science, Technology, Education and Their Application, 244-251.

Warsita, \& Bambang. (2008). Teknologi pembelajaran \& aplikasinya. Jakarta, Rineka.

Wendy K., Adam and Carl E., Wieman. (2008). Problem solving skill evaluation instrumentvalidation studies. Journal of Science Education. https://doi.org/10.1063/1.2508681

Wiyono Ketang and Taufik. (2009). Using computer simulation to impove concept comprehension of physics teacher candidates students in special relativity. Proceeding of the third Internasional Seminar of Science Education, ISBN, 978-602-8171-14-1.

Yusuf, I., Widyaningsih, S.W., \& Purwati, D. (2015). Pengembangan perangkat pembelajaran Fisika Modern berbasis media laboratorium virtual berdasarkan paradigma pembelajaran abad 21 dan Kurikulum 2013. Pancaran Pendidikan, 4(2), 189-200.

Yulianti, D., Khanafiyah, S., \& Sugiyanto. (2012). Penerapan Virtual Experiment Berbasis Inkuiri untuk Mengembangkan Kemandirian Mahasiswa. Jurnal Pendidikan Fisika Indonesia, 8 (2012), 127134. 